\title{
Understanding shallow landslides in Campos do Jordão municipality - Brazil: disentangling the anthropic effects from natural causes in the disaster of 2000
}

\author{
Rodolfo M. Mendes, Márcio Roberto M. de Andrade, Javier Tomasella, Márcio Augusto E. de Moraes, and \\ Graziela B. Scofield \\ National Center for Monitoring and Early Warning of Natural Disasters, Parque Tecnológico/São José dos Campos, Estrada \\ Doutor Altino Bondesan 500,12247-016, São Paulo, Brazil
}

Correspondence: Rodolfo M. Mendes (rodolfo.mendes@ cemaden.gov.br)

Received: 30 June 2017 - Discussion started: 14 July 2017

Revised: 20 November 2017 - Accepted: 21 November 2017 - Published: 3 January 2018

\begin{abstract}
Located in a mountainous area of south-eastern Brazil, the municipality of Campos do Jordão has been hit by several landslides in recent history. Among those events, the landslides of early 2000 were significant in terms of the number of deaths (10), the population affected and the destruction of infrastructure that was caused. The purpose of this study is to assess the relative contribution of natural and human factors to triggering the landslides of the 2000 event. To achieve this goal, a detailed geotechnical survey was conducted in three representative slopes of the area to obtain geotechnical parameters needed for slope stability analysis. Then, a set of numerical experiments with GEO-SLOPE software was designed, including separate natural and anthropic factors. Results showed that natural factors, that is, high-intensity rainfall and geotechnical conditions, were not severe enough to trigger landslides in the study area and that human disturbance was entirely responsible for the landslide events of 2000. Since the anthropic effects used in the simulations are typical of hazardous urban areas in Brazil, we concluded that the implementation of public policies that constrain the occupation of landslide susceptible areas are urgently needed.
\end{abstract}

\section{Introduction}

Due to the combination of frequent, high-intensity, heavy rain on landscapes dominated by narrow valleys and steep slopes, large areas of the south-eastern and southern Brazil are naturally susceptible to landslides. In addition, recent studies by CEPED (2012) indicate that more than 160 million inhabitants live in urban areas (about $90 \%$ of Brazilian population), and that increased urbanization in cities without urban planning and consequent occupation of hazardous areas have led to an increase in this natural disaster. Consequently, landslides are directly associated with the loss of lives, property and infrastructure damage, and environmental destruction. During 2011, for instance, mountainous regions of the Rio de Janeiro state suffered several landslides that caused more than 1500 deaths and severe damage to urban and rural infrastructure (Coelho Netto et al., 2013).

In spite of floods (generally gradual flooding) being the most disruptive natural disaster in terms of economic damages and population affected, landslides have been considered the most severe in terms of death toll (Londe et al., 2014). Although landslide and flash floods usually affect heavily urbanized downtown areas, it is also recognized that poor people living in the outskirts are more vulnerable to these types of disaster. Increased landslide hazard, for instance, has been related to the improper cut-and-fill construction of self-built housing on steep slopes, after the removal of vegetation. In addition, because of the lack of collection systems, sewage is disposed into the hillslope soils, further increasing the risk of triggering landslides as well as the health risks associated with the lack of sanitation.

Among those areas affected by landslides in SE Brazil, the municipality of Campos do Jordão has been hit by several events since the 1970s. The most recent severe landslides occurred in the early days of 2000, leaving 103 people injured, 
10 fatalities and more than 423 houses at risk of collapse (Londe et al., 2014).

Early warning systems used by the civil defence in Campos do Jordão and by CEMADEN (National Center for Monitoring and Early Warning of Natural Disasters) are based on threshold values of $72 \mathrm{~h}$ accumulated rainfall, derived from empirical studies (Tatizana et al., 1987; Santoro et al., 2010). In 2000, rainfall was monitored every $24 \mathrm{~h}$ at 07:00 local time using manual rain gauges, and the threshold value for triggering landslides was based on previous studies in other areas of Brazil. Since the accumulated rainfall values responsible for the occurrence of the landslides of 2000 were well below the critical level proposed in previous studies (Tatizana et al., 1987), it was not possible to conduct a pre-emptive evacuation of many hazardous areas.

Although empirical rainfall thresholds are successfully used in operational warning systems to predict shallow landslides (Lagomarsino et al., 2013), critical rainfall thresholds for triggering landslides vary due to regional and local precipitation distribution, slope morphometry, soil characteristics, lithology, microclimate and geological history (Crosta, 1998; Van Asch et al., 1999). Therefore, the reliability of empirically derived critical rainfall threshold depends entirely on the availability of a significant number of cases relating to the occurrence of landslides and rainfall conditions. Guzzetti et al. (2007) proposed covering regional thresholds for areas of a few to thousands of square kilometres which have the same meteorological, climatic and physiographic characteristics, whereas for local conditions the geomorphology and climate regime are considered to be applicable to areas in the order of hundreds of square kilometres.

After the event of 2000 , new critical $72 \mathrm{~h}$ rainfall thresholds values for landslides were proposed for the area. In addition, the civil defence of the state of São Paulo established new critical rainfall amounts for visually monitoring critical areas in order to detect early signals on the imminence of a landslide. However, the peak rainfall intensities recorded in the event of 2000 have not been repeated since, while irregular occupations continued in many landslide-prone areas. Therefore, a detailed study of the event of 2000 is relevant, not only because of its extreme characteristics but also with the perspective that memory of the 2000 event has faded and its impacts are largely underestimated among many local residents.

In this context, for a limited number of data hydrologic models are relevant for investigating precipitation induced shallow planar landslides (Terlien, 1998).

Given the lack of detailed data from historical landslide events in the municipality of Campos do Jordão, the aim of this study was to understand the factors responsible for triggering the landslides of early 2000 in the area using a numerical model that fully coupled slope stability analysis with saturated/unsaturated transient pore-water pressure simulations.

Physically based hydrological models have been widely applied to predict pore-pressure build-up due to infiltration in shallow landslides (Frattini et al., 2009; Iverson, 2000). Several models based on the infinite slope concepts that integrate hillslope hydrology with slope stability are reported in the literature, for instance SINMAP (Pack et al., 1998), SHALSTAB (Dietrich et al., 1998), TRIGRS (Baum et al., 2002) and GEOtop FS (Rigon et al., 2006).

During the last decade, physically based landslide prediction models have also been successfully used in early warning systems. Models used in such applications include, among others, the Combined Hydrology and Stability Model (CHASM; Thiebes et al., 2014), the High Resolution Slope Stability Simulator (HIRESS; Rossi et al., 2013); the SLopeInfiltration Distributed Equilibrium (SLIDE; Liao et al., 2010; Montrasio and Valentino, 2008), the Shallow Landslides Instability Prediction (SLIP; Montrasio, 2000; Montrasio et al., 2011). Another slope stability model is the modular software package GeoStudio (2012), in which SEEP/W and SLOPE/W plugins are used to simulate the instability of slopes during extreme rainfall events. Although GEOSLOPE is a simplified "single slope" model, it has been used in several previous studies to understand the effect of infiltration on rainfall-induced landslides (for instance $\mathrm{Ng}$ and Shi, 1998; Gasmo et al., 2000; Kim et al., 2004; Huat et al., 2006; Oh and Vanapalli, 2010; Acharya et al., 2016), producing very good results (Tofani et al., 2006).

In this study, we analysed several scenarios that included the relative influence of natural and anthropic factors that prevail in the area and identified the most critical factors responsible for the severe landslides of 2000 using the GeoStudio (2012) software due to its versatility in handling separate natural and anthropic boundary conditions.

In addition, we analysed whether the threshold rainfall values established by the civil defence are adequate for early warnings of landslide occurrence, taking into account today's patterns of landslide-prone areas.

\section{Material and methods}

\subsection{Study site}

The study site is the municipality of Campos do Jordão in the state of São Paulo, located in a mountainous region along the Mantiqueira Mountains (Fig. 1). In geological and geomorphological terms, the Campos do Jordão plateau is a crystalline plateau block with elevations of more than $2000 \mathrm{~m}$ above sea level and bordered by steep cliffs that rise approximately $1500 \mathrm{~m}$ over the adjacent Paraíba valley (Almeida, 1976). The relief, strongly conditioned by the structures and lithology of the area, is characterized by the presence of high hills and erosive depressions. On the basis of these amphitheatres peat depressions occur (Modenesi-Gauttieri and Hiruma, 2004) where deposits of organic clay of varying thickness are found. The geological and geotechnical characteristics of the deposits of organic clay and its quite sensi- 
Table 1. Historical disasters in Campos do Jordão municipality. Source: Ridente et al. (2002) and Andrade (2014).

\begin{tabular}{lllll}
\hline Process & Location & Year & Damages & Causes \\
\hline Earthflow & Vila Albertina & 1972 & $\begin{array}{l}17 \text { fatalities } \\
60 \text { houses buried }\end{array}$ & $\begin{array}{l}\text { Saturated soil (8 m thick), } \\
\text { loading and vibration due to } \\
\text { construction activities }\end{array}$ \\
\hline Landslide & Britador, Vila Santo Antonio & 1991 & 149 affected & $214.5 \mathrm{~mm}$ of rainfall \\
& and Vila Paulista Popular & & $\begin{array}{l}11 \text { houses buried } \\
\text { in } 3 \text { days }\end{array}$ \\
& & & 10 fatalities & \\
\hline $\begin{array}{l}\text { Landslide and } \\
\text { mudflow }\end{array}$ & Britador, Vila Albertina, & 2000 & 453.2 mm in 5 days \\
& Vila Santo Antônio, & & 1840 affected & \\
& Vila Nadir Vila Sodipe and & & & \\
& Vila Paulista Popular & & & \\
\hline
\end{tabular}

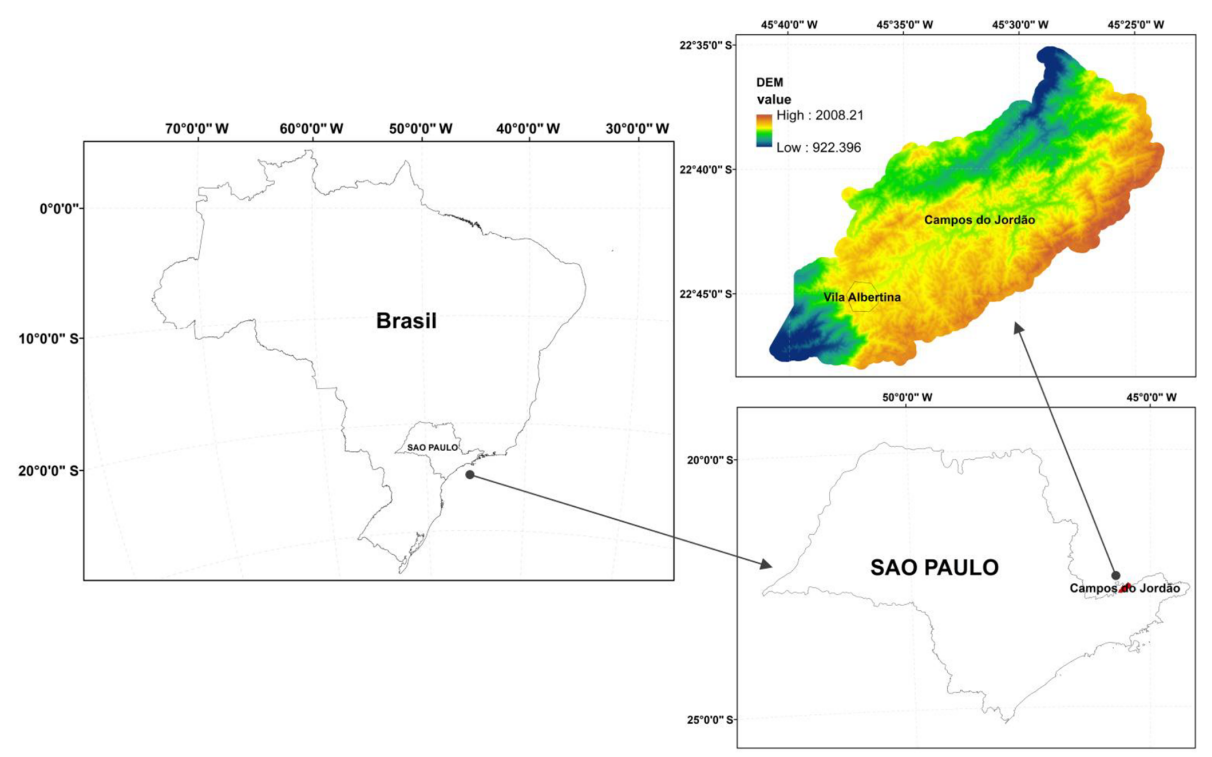

Figure 1. Geographical location of the Campos do Jordão municipality and an inset of the study site.

tive behaviour to sudden human interventions that alter their original equilibrium conditions have conditioned the slopes stability in the urban area of the municipality of Campos do Jordão (Ogura et al., 2004).

The area where Campos do Jordão is located was occupied by Portuguese settlers during the 18th century. During the hygienist movement (late 19th and early 20th centuries), various health facilities were established in the town, mainly for tuberculosis treatment. Since 1940, the town has experienced a large population growth and urban expansion due to the development of tourism: the number of inhabitants increased from 13000 in 1950 to more than 50000 according to the estimates, with density of 164.76 pop km$~^{-2}, 99.3 \%$ of which live in the urban area (IBGE, 2016).

The process of accelerated urbanization, especially from the 1970s, of areas with unfavourable geotechnical characteristics, has been pointed out as responsible for most of the natural disasters in Campos do Jordão (Ridente et al., 2002).
Table 1 shows the most important events in terms of dead toll and damages recorded in the area.

Landslides in the study area are classified as shallow and translational, with depths of the rupture surfaces less than $2 \mathrm{~m}$. Depending on the position of the rupture, three different processes are observed: the rupture surface occurs in the residual soil of undisturbed ground, the rupture surface occurs in the residual soil of a slope cut, and the rupture surface occurs at the base of the landfill deposit or in the slope residual soil with mobilization of the overlying landfill. The last landslide types are more harmful since they mobilized larger amounts of material. In the case of the event of 2000 (Fig. 2), which is the focus of this study, rainfall began on 31 December 1999 and continued almost uninterrupted for 4 days with high-intensity rainfall bursts. According to the Brazilian Center for Weather Forecasting and Climate Studies (CPTEC), daily rainfall from 31 December 1999 to 5 January 2000 was $78.5,101,120,60,144.5$ and $10.5 \mathrm{~mm}$ 


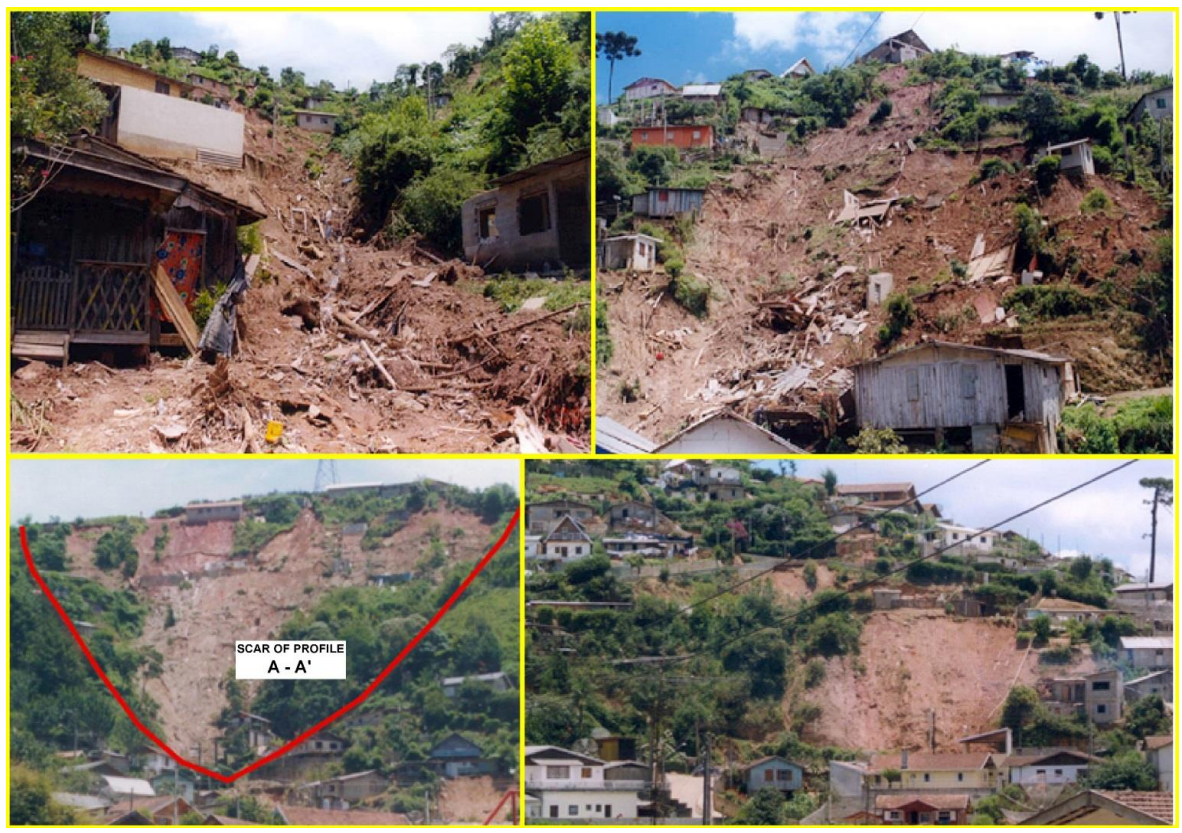

Figure 2. Shallow landslides that happened in 2000 at the study site (Source: Ridente et al., 2002).

(Ridente et al., 2002). Landslides associated with this event were considered to be one of the most severe in urban areas in Brazil, since hundreds of landslides occurred, mostly in slopes in poor neighbourhoods where houses are constructed over cut-and-fill areas.

Based on the landslide events of 1972, 1991 and 2000, Ridente et al. (2002) proposed an approximation of the critical rainfall necessary for the deflagration of landslides in Campos do Jordão, revealing that, in most cases, landslides are due to occur after 3 days of about $200 \mathrm{~mm}$ of rain, with daily rainfall of at least $70 \mathrm{~mm}$ during the last day analysed. The civil defense preventive plan of the state of São Paulo uses three indexes of precipitation accumulated over 3 days $(60,80$ and $100 \mathrm{~mm})$ as critical thresholds for warning levels (Santoro et al., 2010). These thresholds were based on the studies carried out by Tatizana et al. (1987) and have been considered critical for issuing early warnings based on rainfall observation and forecasting.

With the aim to develop relationships for the prediction of mass movements in the area, Ahrendt (2005) attempted to correlate precipitation with the occurrence of landslides based on the critical intensity curves obtained by Tatizana et al. (1987) for the Serra do Mar in the municipality of $\mathrm{Cu}-$ batão, and by D'Orsi (1997) for the Mantiqueira Mountains in the municipality of Rio de Janeiro. Results showed that the occurrences of Campos do Jordão were below the critical levels of those areas, indicating that the rainfall intensities required for triggering landslides in Campos do Jordão are much lower than the other sites. Therefore, the study of Ahrendt (2005) concluded that rainfall characteristics that trigger landslides in Campos do Jordão are very unique, and a different and more detailed approach was needed.

Considering the limited historical data on landslide occurrence and the few previous studies in the area, it is extremely difficult to define accurate critical threshold rainfall values that trigger landslides, in particular, the effects of the accumulated rainfall on the water movement and its relationship to rapid mass movements.

The Brazilian National Centre for Monitoring and Early Warnings of Natural Disasters (CEMADEN) began to monitor Campos do Jordão in the summer of 2012. Most of the occurrences were observed in cut-and-fill slopes, with evident contribution of waste water and microdrainage deficiency. In recent history occurrences of great magnitude were not recorded; however, the destruction of houses or even the prohibition of occupying damaged houses is a recurring problem.

\subsection{Soil moisture monitoring}

Soil moisture was monitored hourly to a depth of $3 \mathrm{~m}$ over 12 months (1 January 2016 to 31 December 2016), using two EnviroScan ${ }^{\mathrm{TM}}$ probes installed next to the borehole SD03 (Fig. 3). EnviroScan ${ }^{\mathrm{TM}}$ probes are installed in customized access tubes manufactured by Sentek Pty. Ltd. Inside the EnviroScan ${ }^{\mathrm{TM}}$ probe six Sentek capacitance sensors were distributed. The capacitance sensor gives an output in volumetric water content (millimetres of water per $100 \mathrm{~mm}$ of soil measured). This is converted from a scaled frequency reading using a default calibration equation, which is based on 


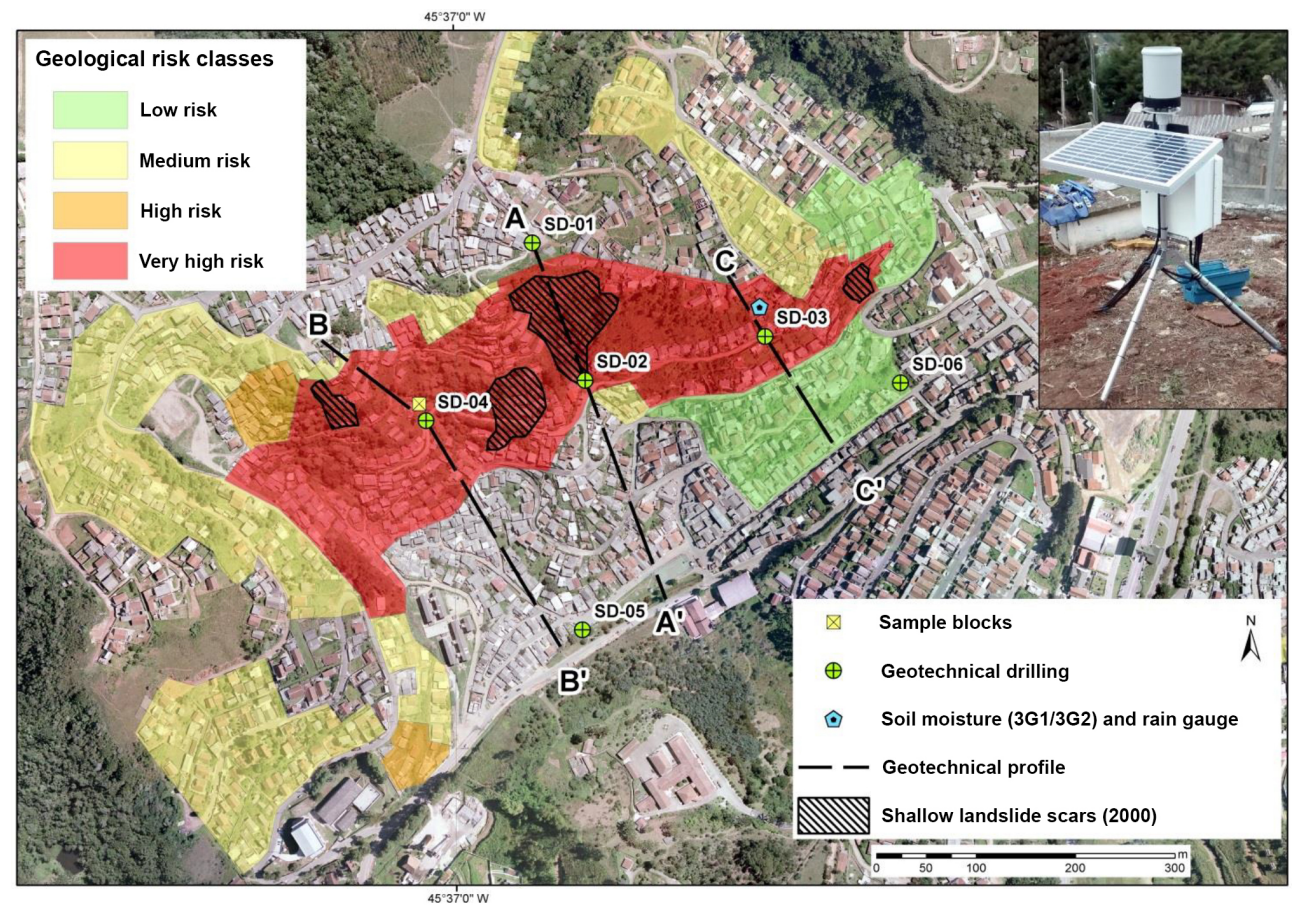

Figure 3. Satellite image of the study site showing the location of monitoring instruments (symbols), geotechnical transects (dotted lines along the slopes), landslide susceptibility areas indicating the level of risk (areas shaded in yellow, orange and red) and scars of previous shallow landslides (black cross-hatched area).
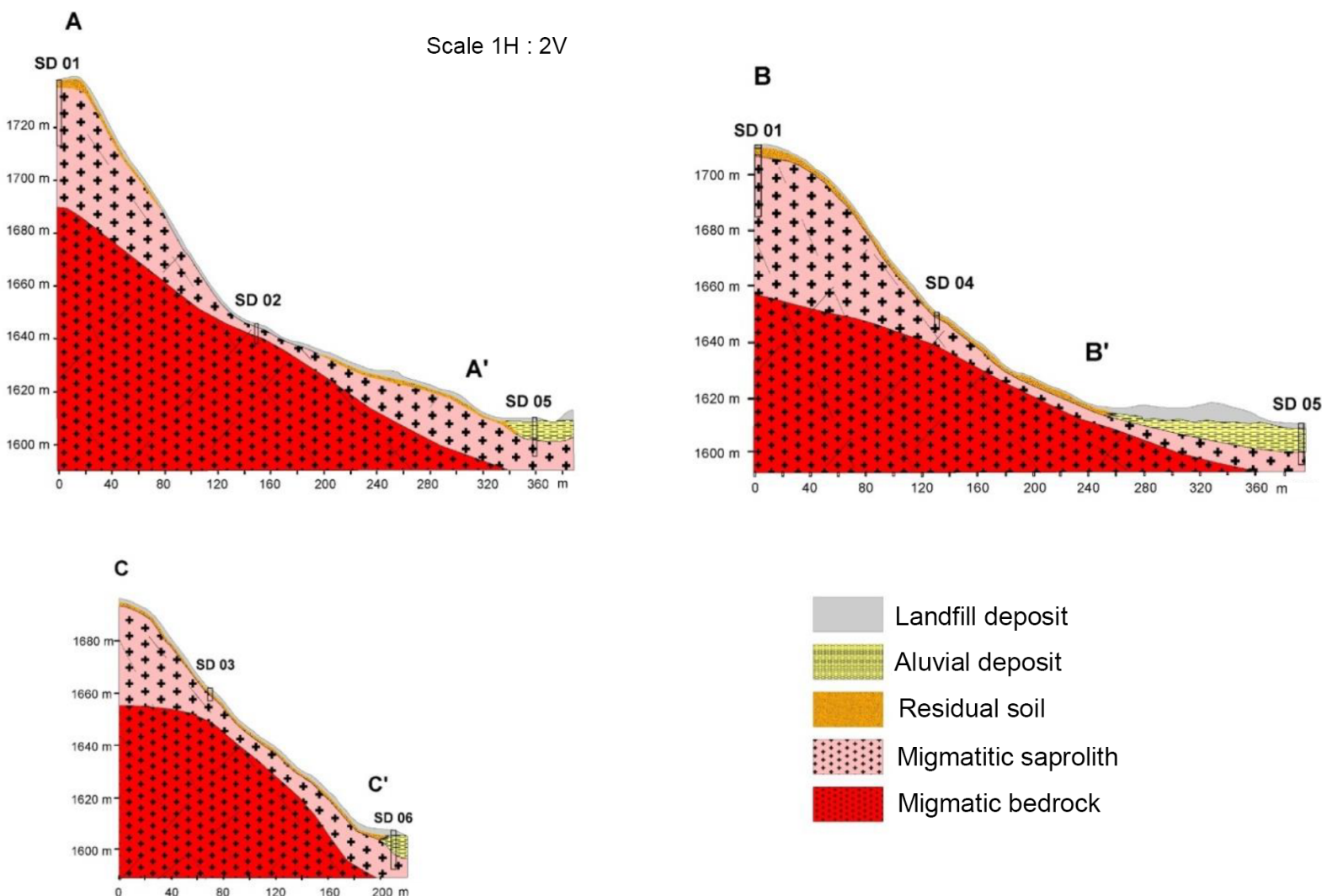

Figure 4. Geological-geotechnical profiles of the study area derived from the geotechnical survey. 
data obtained from numerous scientific studies in a range of soil textures.

Before a Sentek capacitance sensor can be installed in the soil, it must have minimum and maximum values set. This is done using air and water around each sensor (lecture limits of the volumetric water content - dry and saturated).

Soil moisture was monitored during 2016 at hourly intervals and to a depth of $3.0 \mathrm{~m}$ using two EnviroScanTM (Campbell Scientific, 2016) probes installed next to the borehole SD-03 (Fig. 2). Each probe included six capacitance sensors that measured soil moisture every $0.5 \mathrm{~m}$, that is, at the depths of $0.5,1.0$, and $3.0 \mathrm{~m}$, which allowed moisture variations of the landfill, residual and saprolite layers to be monitored. Before the EnviroScanTM capacitance probes were installed in the soil, maximum and minimum values were normalized by matching the raw readings from each sensor at both $0 \%$ (held in air) and $100 \%$ water levels (submerged in water).

\subsection{Geotechnical survey}

SPT (standard penetration test) boreholes were drilled along three profiles of the study site (A-A', B-B', C-C' in Fig. 3) at six different positions along the slopes (SD-01 to SD-6; Fig. 4). Disturbed and undisturbed samples were taken from the boreholes for the determination of the parameters used for stability analysis.

Three undisturbed samples were collected in migmatitic saprolite block close to the SD-04 borehole. This material occurs anisotropically and discontinuously, because it presents significant textural variation resulting from the heterogeneity of the parental rock, being predominantly formed by silt and fine sand, with variable occurrence of clay. From the six boreholes (SD-1 to SD-6) and the three undisturbed blocks it was possible to obtain a total of 12 soil samples to perform geotechnical characterization tests of the study area following Brazilian standard procedure.

Disturbed and undisturbed samples collected were used to perform a grain size analysis test (ABNT, 1984b, 1995), soil particle density (ABNT, 1984a), bulk density, specific dry mass and Atterberg limits (ABNT, 1984c, d). Parameters of effective cohesion $\left(c^{\prime}\right)$ and effective friction angle $\left(\varphi^{\prime}\right)$ were obtained from saturated direct shear tests, using square-shaped undisturbed samples with $60 \mathrm{~mm}$ width and height of $25 \mathrm{~mm}$. The soil samples were in their natural state, being representative of the residual and saprolite soil layers. During the consolidation step, all specimens were saturated for $24 \mathrm{~h}$ and subjected to net normal stresses of 25 , 50 and $100 \mathrm{kPa}$. Then, in the shearing phase, a constant velocity of $0.033 \mathrm{~mm} \mathrm{~min}^{-1}$ was applied. Vertical and horizontal displacements were recorded during the consolidation and shearing phases.

After saturation of soil samples for $12 \mathrm{~h}$, water retention curves (WRCs) of the residual soils layers were obtained using a pressure plate for suctions $<100 \mathrm{kPa}$ and filter paper for suctions $\geq 100 \mathrm{kPa}$ for the drying path of the samples following the recommendation of Marinho and Oliveira (2006). Results showed that the differences in water retention values at the transition between the methods were not significant, making further adjustments unnecessary (Fig. 8). The saturated hydraulic conductivity (Ksat) was obtained in the laboratory using a constant head permeameter. Hydraulic conductivity functions were estimated from the WRC, Ksat using the Van Genuchten (1980) model. In the case of landfill deposits, the values of Ksat for different soil textures were those obtained by Ahrendt (2005) from core measurements.

\subsection{Modelling experiments}

The modelling of the stability and seepage analysis was divided in two parts: (1) transient unsaturated seepage analysis and (2) stability analyses coupled with the results from the previous step.

For the seepage analysis, 35 days of accumulated rainfall for the period 1 December 1999 to 4 January 2000 was considered, since the event triggered several landslides in the study area (Ahrendt and Zuquette, 2003). In addition to the geotechnical parameters, anthropic factors that induce landslides typical of Brazilian urban slopes, specifically housing load, man-made cuts and leakage from pipes, were included in the modelling experiment with the aim of analysing the degree of influence of these factors on the occurrence of landslides in the study area during 2000 (Figs. 4, 5 and 6).

The boundary conditions were set according to field observations on the landslide area and the boundary conditions used by Rahardjo et al. (2007). The non-saturated transient flux results were obtained for two cases considering only the accumulated rainfall and rainfall with linear leakage along the cut slope (Fig. 5). The initial pore-pressure values used in the transient flow analysis were obtained indirectly from the WRC and the data on the soil moisture sensors installed in the study area (Figs. 7 and 8). Next, the factor of safety (FS) for the slope was estimated from the transient seepage modelling coupled with the stability analysis tool (GEO-SLOPE, 2012a). All the stability analyses were conducted considering the theory of static equilibrium of forces and momentum. The FSs were calculated using the geotechnical and anthropic parameters, obtained from the method of Morgenstern-Price, which considers circular and non-circular rupture surfaces. All the simulations allowed the slope stability module SLOPE/W to identify the most critical rupture surface (Fig. 6). Therefore, the values of the slope safety factor (FS) were the lowest of all conditions analysed.

\section{Results}

\subsection{Geotechnical survey}

The results of the granulometric analyses of the residual and saprolite layers of the three profiles studied are presented in 


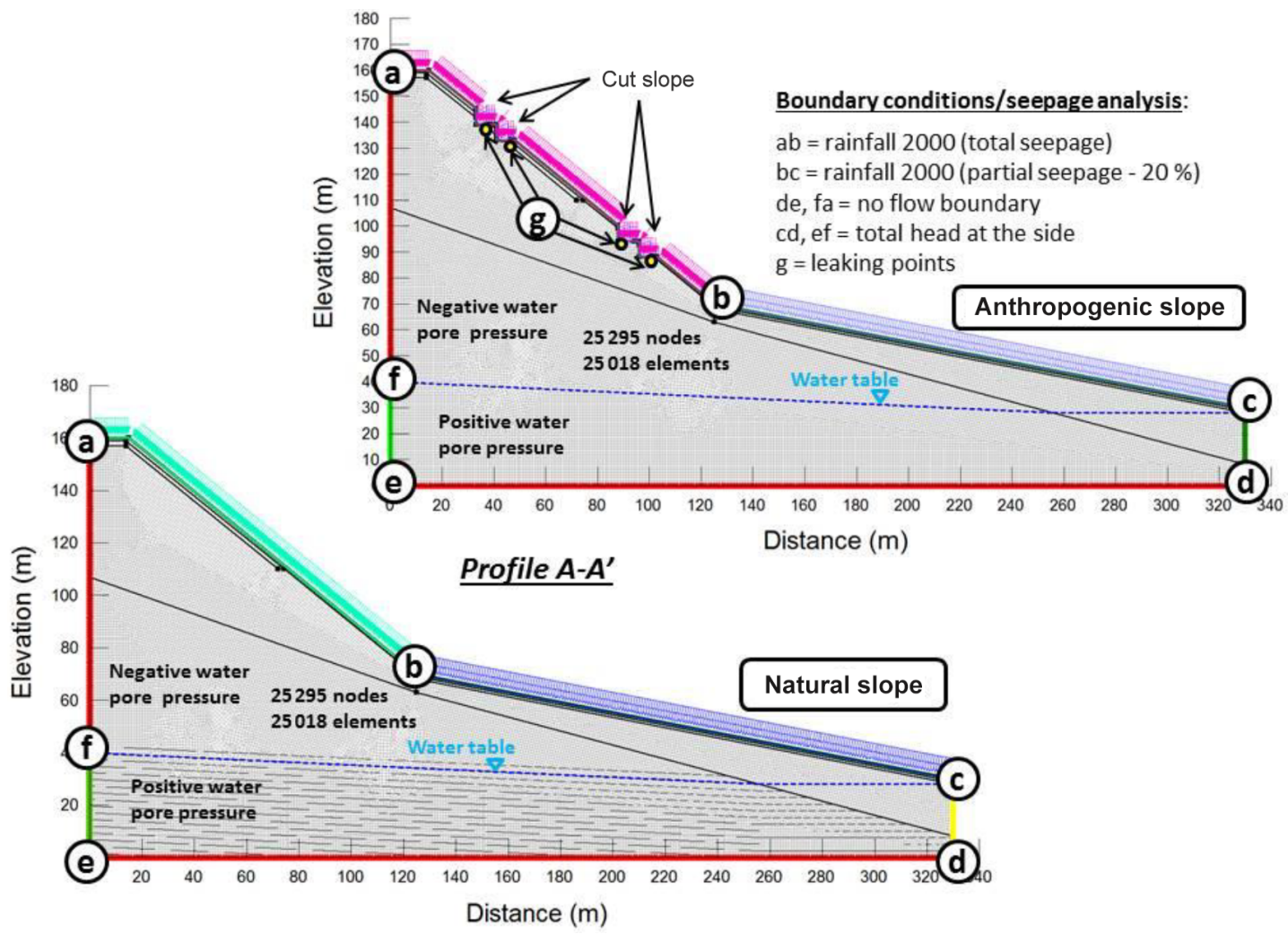

Figure 5. Slope geometry and boundary conditions used in the unsaturated transient seepage analysis with natural and anthropogenic factors (rainfall, cut slope and leakage).

Table 2. Results of the geotechnical survey of soils of the study areas.

\begin{tabular}{|c|c|c|c|c|c|c|c|c|c|c|c|c|c|c|}
\hline Sample & $\begin{array}{r}\text { Depth } \\
(\mathrm{m})\end{array}$ & $\begin{array}{l}\text { Soil } \\
\text { layer }\end{array}$ & USCS & $\begin{array}{r}\text { Unit } \\
\text { weight } \\
\left(\mathrm{kN} \mathrm{m}^{-3}\right)\end{array}$ & $\begin{array}{r}\text { Effective } \\
\text { cohesion } \\
(\mathrm{kPa})\end{array}$ & $\begin{array}{r}\text { Effective } \\
\text { friction } \\
\text { angle }\left(^{\circ}\right)\end{array}$ & $\begin{array}{r}\text { Hydraulic } \\
\text { conduct } \\
\left(\mathrm{m} \mathrm{s}^{-1}\right)\end{array}$ & $\begin{array}{r}\text { Gravel } \\
(\%)\end{array}$ & $\begin{array}{r}\text { Sand } \\
(\%)\end{array}$ & $\begin{array}{l}\text { Silt } \\
(\%)\end{array}$ & $\begin{array}{r}\text { Clay } \\
(\%)\end{array}$ & $\begin{array}{r}w_{\mathrm{L}} \\
(\%)\end{array}$ & $\begin{array}{r}w_{\mathrm{P}} \\
(\%)\end{array}$ & $\begin{array}{r}\text { IP } \\
(\%)\end{array}$ \\
\hline \multirow{3}{*}{ SD-01 } & 2.0 & $\mathrm{R}$ & SC & 18.3 & 37 & 56 & $4.44 \times 10^{-6}$ & 10 & 53 & 25 & 12 & 27 & 18 & 9 \\
\hline & 4.6 & S & SC & 19.1 & 18 & 37 & $9.46 \times 10^{-6}$ & 0 & 53 & 35 & 12 & 35 & 22 & 13 \\
\hline & 6.6 & $S$ & $\mathrm{SC}$ & 17.9 & 2 & 49 & $7.93 \times 10^{-6}$ & 0 & 59 & 27 & 14 & 29 & 20 & 9 \\
\hline \multirow{2}{*}{ SD-02 } & 2.6 & S & $\mathrm{SC}$ & 21.4 & 19 & 34 & $1.18 \times 10^{-6}$ & 5 & 50 & 21 & 24 & 28 & 17 & 11 \\
\hline & 4.6 & S & SM & 17.5 & 14 & 42 & $3.76 \times 10^{-6}$ & 0 & 73 & 14 & 13 & 33 & 20 & 13 \\
\hline \multirow{2}{*}{ SD-03 } & 1.6 & $\mathrm{~S}$ & SM-SC & 18.1 & 22 & 43 & $5.25 \times 10^{-6}$ & 1 & 59 & 29 & 11 & 22 & 15 & 7 \\
\hline & 2.6 & $S$ & SM-SC & 16.8 & 2 & 52 & $6.13 \times 10^{-7}$ & 5 & 55 & 30 & 10 & 23 & 17 & 6 \\
\hline SD-05 & 12.8 & $S$ & $\mathrm{SC}$ & 17.5 & 48 & 54 & $2.77 \times 10^{-7}$ & 0 & 55 & 33 & 12 & 32 & 21 & 11 \\
\hline SD-06 & 7.6 & $S$ & SM & 17.8 & 42 & 28 & $3.09 \times 10^{-6}$ & 1 & 72 & 15 & 12 & - & - & - \\
\hline Block 1 & 2.0 & $\mathrm{~S}$ & SM & 16.0 & 2 & 53 & $9.37 \times 10^{-7}$ & 0 & 72 & 21 & 7 & - & - & - \\
\hline Block 2 & 2.0 & S & SM & 16.0 & 49 & 37 & $2.98 \times 10^{-6}$ & 0 & 55 & 42 & 3 & - & - & - \\
\hline Block 3 & 3.0 & $\mathrm{~S}$ & SM & 16.0 & 13 & 46 & $4.44 \times 10^{-6}$ & 0 & 58 & 28 & 14 & - & - & - \\
\hline
\end{tabular}

* Residual soil (R); saprolite (S).

Fig. 7. Residual layer (sample SD-01/2.0 m) can be classified as clayey sand, with percentages of sand and silt of 53 and $25 \%$. The soil samples representative of the saprolite layer showed a significant variation in the percentage of the clay fraction ( 3 to $24 \%$ ), silt (14 to $42 \%$ ) and sand (53 to $73 \%$ ), indicating that soil profiles are heterogeneous, which is in agreement with the textural characteristics of its parent material (migmatitic gneiss). Therefore, it is expected 


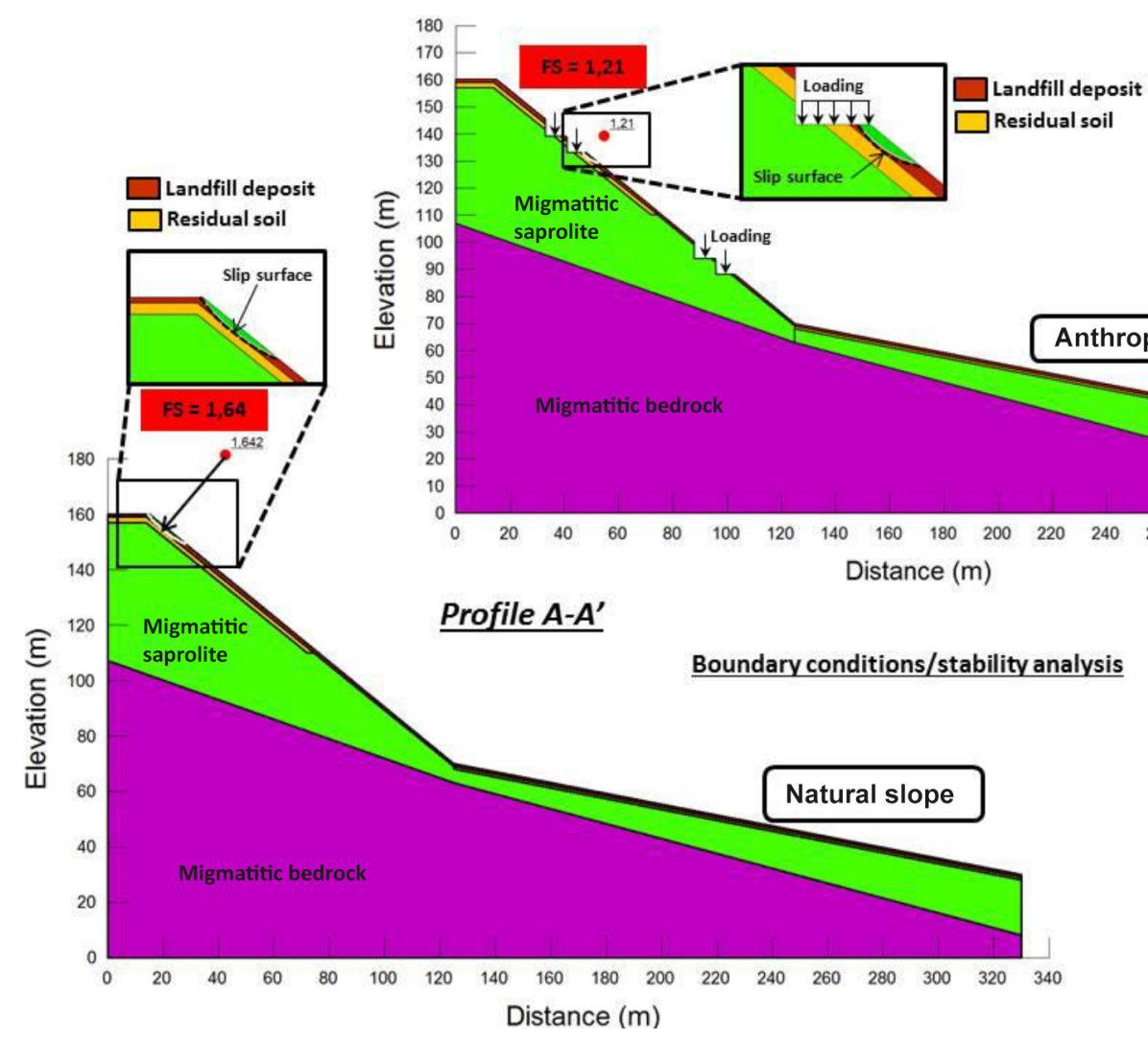

Figure 6. Slope geometry and boundary conditions used in the stability analysis with natural and anthropogenic factors (rainfall, cut slope, loading and leakage).

that the mechanical and hydraulic properties of this soil layer present high variability. The general results of the geotechnical tests (general characteristics, shear strength and saturated hydraulic conductivity) of the samples of the representative soils of the studied area are presented in Table 2.

Analysing the values of the effective strength parameters $\left(c^{\prime}\right.$ and $\left.\varphi^{\prime}\right)$ and saturated hydraulic conductivity (Table 2), the values representative of the saprolite layer showed significant variability: the coefficient of variation was $85 \%$ for the effective cohesion, $20 \%$ for the effective friction angle, and $89 \%$ for the saturated hydraulic conductivity, reflecting the heterogeneity character of the parent material. The high values of the resistance parameters shown in Table 2 can be explained with the high heterogeneity of the residual gneiss soil, such as the presence of quartz particles and other minerals of considerable size in the specimens tested, which confer them high resistance. In addition, the values of the resistance and Ksat parameters obtained in this study are close to mean reference values of residual gneiss soils that are representative of other Brazilian sites (Costa Filho and Campos, 1991; Ahrendt, 2005; Reis et al., 2011).

Figure 8 shows the water retention curves of the soil layers that are representative of the profiles. In general, the residual and saprolite layers are able to hold more water than the landfill deposit. For example, for a field matrix suction level of $100 \mathrm{kPa}$, the volumetric moisture values of the landfill deposit, residual soil and saprolite layers are 0,06, 0,24, $0,26 \mathrm{~m}^{3} \mathrm{~m}^{-3}$.

\subsection{Soil moisture data}

Soil moisture data from 2016 from the EnviroScanTM probes (3G1 and 3G2) are presented in Fig. 9. The data from 3G1 (upper graph of Fig. 9) showed that in the sensor installed at a lower depth $(0.5$ to $1 \mathrm{~m})$, which is representative of the landfill deposit (green curve) layer, variations are larger than moisture variations $(\Delta \theta=32 \%)$, with maximum and minimum water content values recorded in March $(46 \%)$ and April (14\%), respectively. At deeper layers (1$3 \mathrm{~m}$ deep) that are representative of the residual and saprolite layers (black and red curves), time variation of soil moisture is much lower ( $\Delta \theta=10 \%$, on average). In the residual layer (black curve), maximum and minimum values of soil moisture were verified in January (38\%) and May (27\%), respectively. In the case of the saprolite layer (red curve), the maximum soil moisture value occurred in June $(40 \%)$ and and the minimum in May (32\%). The different dynamics among the three soil layers not only reflect differences in the retention properties of each layer considered but also the deep soil 


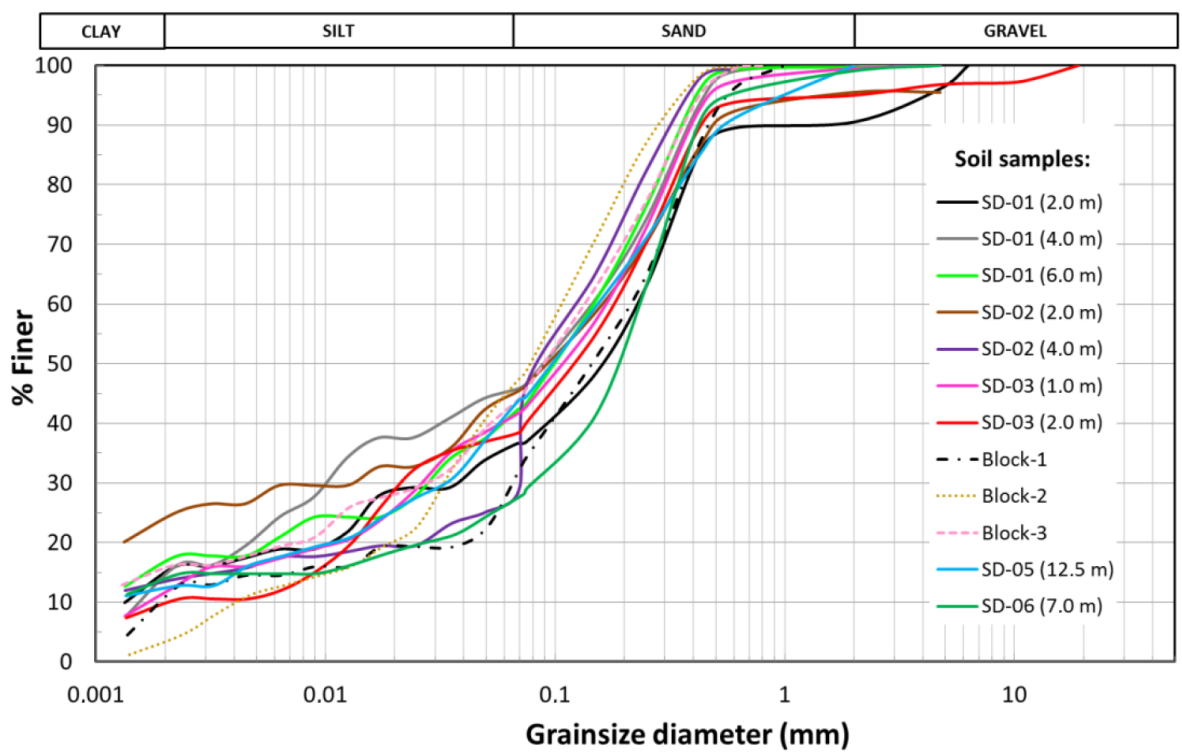

Figure 7. Granulometric distribution for the residual soil and the saprolite of the six boreholes analysed (SD-01 to SD-06) and for the undisturbed soil cores (Block 1 to Block 3).
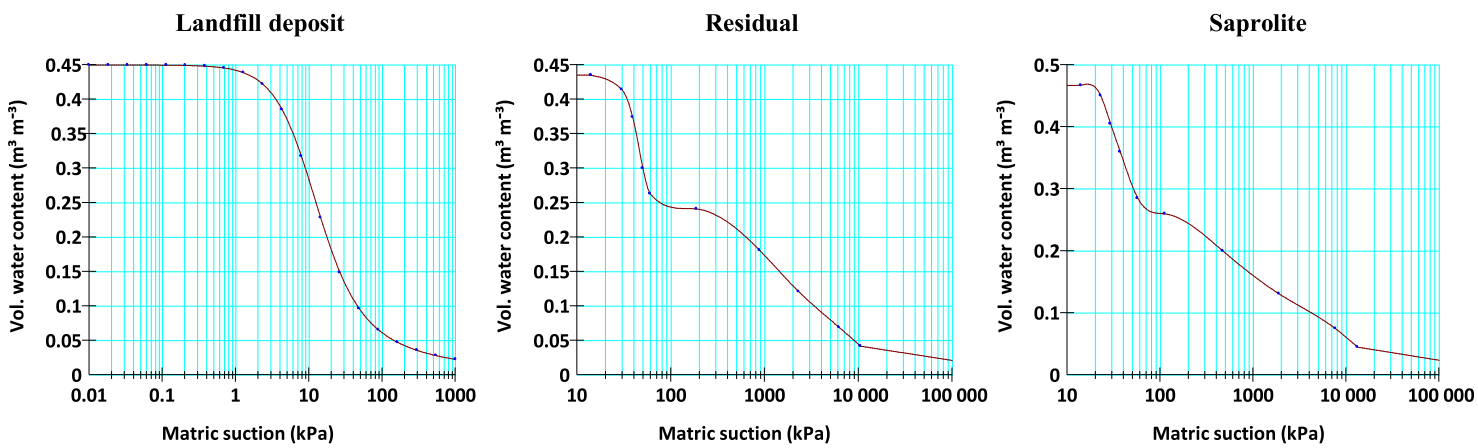

Figure 8. Water retention curves of the three soil types used in transient seepage analysis.

water dynamics down through the soil profiles. This explains why the upper layer (landfill deposit) shows a more spiky behaviour in response to the rainfall, while the other two layers exhibit gradual and delayed variations related to deep water percolation.

Analysing the data on the probe 3G2 (lower graph of Fig. 9), it is clear that the soil moisture variation of the sensor of the surface layer, representative of the landfill deposit layer (green curve), was significantly lower $(\Delta \theta=15 \%)$ compared to the same layer of probe $3 \mathrm{G} 1$. Maximum and minimum soil moisture values were recorded in September (43\%) and August (28\%), respectively. Deeper within the residual and saprolite layers (black and red curves), time variation of soil moisture variation is similar to the measurements of probe $3 \mathrm{G} 1$ ( $\Delta \theta=9 \%$, on average). For the residual layer (black curve) maximum and minimum soil moisture values were observed in January (31\%) and May (21\%), respectively, while in the saprolite layer (red curve) the maxi- mum was observed in January (37\%) and the minimum occurred in August (30\%).

Contrasting differences in the soil moisture behaviour of the landfill deposit from the probes $3 \mathrm{G} 1$ and $3 \mathrm{G} 2$ suggest that the variability of soil parameters is higher in the top layer. This was expected considering that this layer is the result of the cut-and-fill processes mixed with construction waste of several types.

\subsection{GEO-SLOPE simulations input data}

Table 3 summarizes the parameters used in the numerical simulation with GEO-SLOPE software, based on the geotechnical survey and information extracted from different sources.

Regarding the geotechnical properties, in order to reduce the uncertainties due to the heterogeneity of the parent material, the mean values of the resistance $\left(c^{\prime}\right.$ and $\left.\varphi^{\prime}\right)$, bulk 

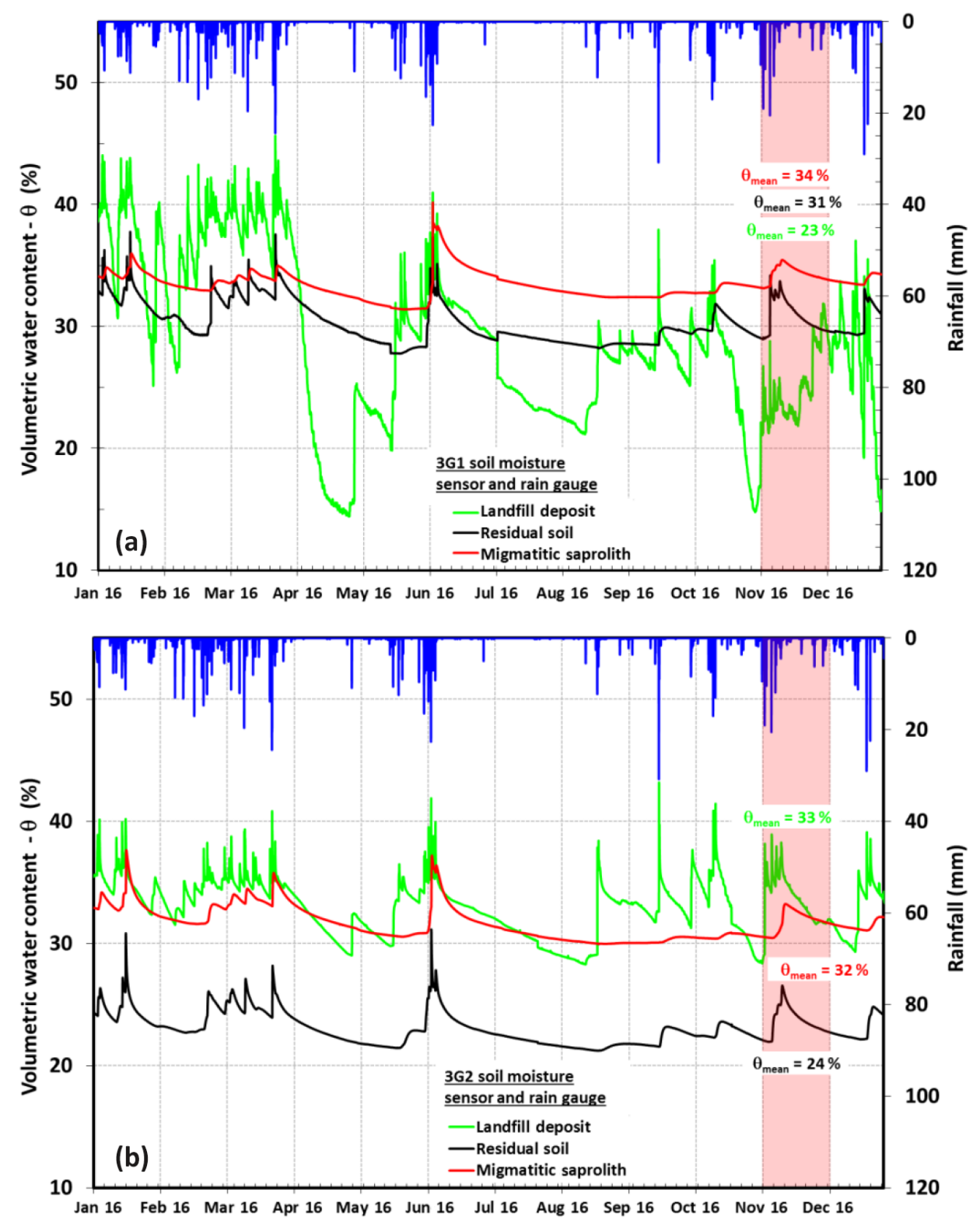

Figure 9. Time variation of soil moisture at different depths during 2016 in the study area measured with the sensors 3G1 (a) and 3G2 (b).

density and saturated hydraulic conductivity parameters for saprolite and residual (Table 2) were used in the flow and stability modelling. As mentioned before, for the landfill deposit, the geotechnical parameters were those obtained by Ahrendt (2005).

Based on the field information from previous studies in Brazil, the anthropic factors considered in the simulations were point leakage sources of $1.0 \mathrm{~m}^{3} \mathrm{day}^{-1}$ (SABESP, 1993, 2016) for simulations that include leakage, distributed load due to single-storey housing of $2.0 \mathrm{kNm}^{-2}$ (ABNT, 1980) and height of the cutting slope (based on field data). In the case of the simulations that include leakage, one constant value of $1.0 \mathrm{~m}^{3} \mathrm{day}^{-1}$ was considered in the cut slope, from the 10th day of the simulation to the 35st day, since numerical experiments showed that a time interval of 10 days was adequate to minimize the effect of the uncertainties of initial pore-pressure conditions used in the simulations. It should be noted that this strategy helped to separate the effect of leakage from other anthropic factors, without impacting the results at the end of the simulation period (day 35).

For the transient flow analysis, the initial conditions of the simulations were derived assuming initial soil moisture values of $0.33,0.31$ and 0.34 , for the landfill deposit, residual and saprolite layers. These values correspond to the average of the highest soil moisture values of the two probes dur- 

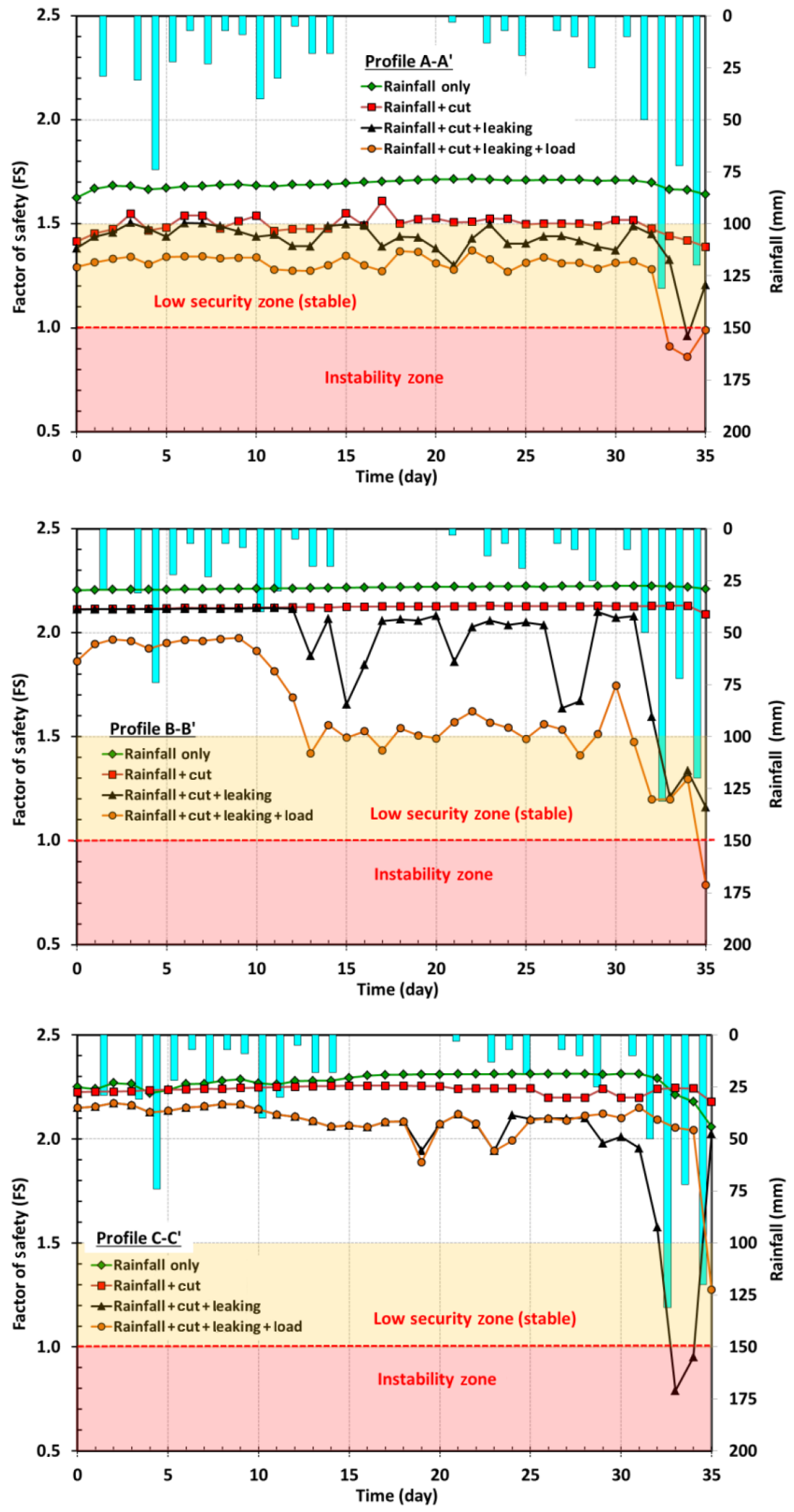

Figure 10. Time variation of the slope safety factor for natural conditions and taking into account the additional effects introduced by anthropic disturbances on profiles $\mathrm{A}-\mathrm{A}^{\prime}, \mathrm{B}-\mathrm{B}^{\prime}$ and $\mathrm{C}-\mathrm{C}^{\prime}$. 


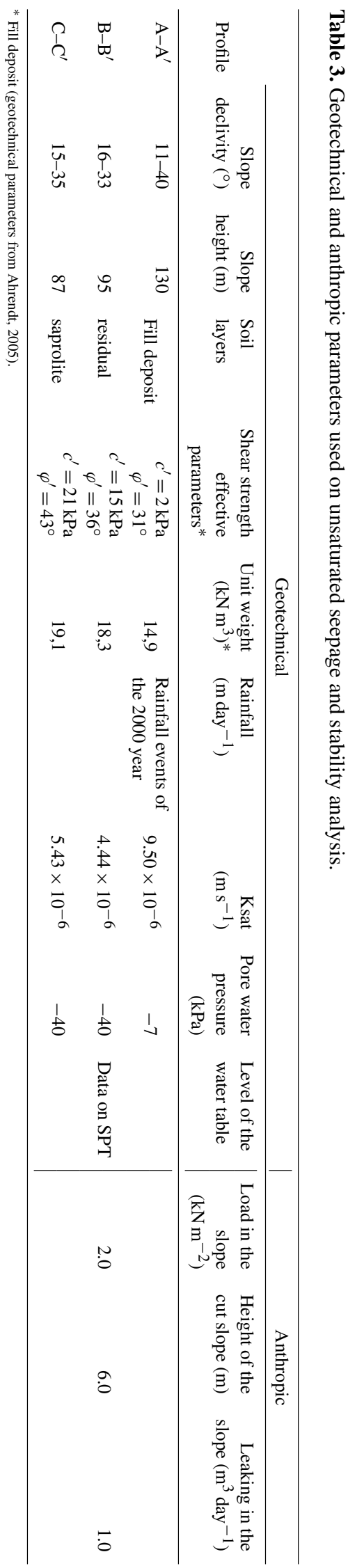

ing November 2016 and are indicated by the light-red-shaded area of Fig. 9.

Subsequently, the mean moisture values were used to obtain the initial values of matrix suction from the representative water retention curves in each layer of the profile (Fig. 8). This choice of the initial values of matrix suction of the numerical experiments proved to be crucial to achieve a fast and coherent convergence of pore-pressure distribution of soil layers in the simulations, since they are representative of the 35 days period considered in the flow analysis (from 1 December 1999 to 4 January 2000). Based on this approach, the values of negative pore pressure (matrix suction) were $-10 \mathrm{kPa}$ for landfills, $-40 \mathrm{kPa}$ for residual and $-40 \mathrm{kPa}$ for the saprolite.

\subsection{Slope safety factor analysis}

Figure 10 shows the time variation of the slope safety factor (FS) during 35 days for the 2000 rainfall for the three profiles. In Fig. 10, two "warning zones" are considered: zone of instability FS $<1.0$, where ruptures should occur and low stability zone, $1.0<\mathrm{FS}<1.5$, which indicates a low possibility of landslide occurrence. In this warning zone the Brazilian Association of Technical Standards (ABNT, 1991) established the following conditions for the safety degree of the slope: high $(1.3 \leq \mathrm{FS}<1.5)$, mean $(1.15 \leq \mathrm{FS}<1.3)$, low $(1.0 \leq \mathrm{FS}<1.15)$.

For all three profiles analysed, it is clear that the effect of daily rain on the decrease in the FS (green line) was practically insignificant, with FS values above the 1.5 threshold (high safety degree of the slope), indicating a very low likelihood of landslides. In the rainfall-only scenario, the variations in FS values are due to the geotechnical and geomorphological characteristics of the analysed profiles only. For the rainfall-only scenario, the difference between FS values in the three profiles are mainly due to the surface slope, since the profile $\mathrm{AA}^{\prime}$ is steeper than $\mathrm{CC}^{\prime}$ ' which is steeper than $\mathrm{BB}^{\prime}$ due to differences in the thickness and location of the layers along the slope (Fig. 4) and the water table profile, which is related to the soil layers.

For the second scenario considered in the analysis of the stability, which includes cut-and-fill effects besides rainfall (red line in Fig. 10), it was verified that terrain cuts had a minor effect on the slope safety factor. Except for the case of the $\mathrm{A}-\mathrm{A}^{\prime}$ profile, which presents the FS condition $<1.5$ between the 32th and 35th days after the beginning of rainfall, FS values were above the 1.5 threshold. However, it is important to note that, in the case of the profile $\mathrm{A}-\mathrm{A}^{\prime}$, the decrease in FS was more pronounced than in the other profiles analysed, which was directly related to the positioning of the cuts considered along the slopes and located based on field information. The configuration of the cuts used in this profile favour the wetting of the topsoil and consequently affected the whole profile stability. 
The third scenario of Fig. 10 (black line), which considered the joint influence of two anthropic factors (cut and leakage) and the rainfall of 2000, shows significant variations in the FS values. For the profile A-A', FS values remained below the threshold of 1.5, while in the other two profiles FS dropped below 1.5 between the 32 nd and 35 th days of simulations in the case of the $\mathrm{B}-\mathrm{B}^{\prime}$ profile and on day 17 for the $\mathrm{C}-\mathrm{C}^{\prime}$ profile. It should be noted that, after the 11 th after the beginning of simulation, FS values become sensitive to rainfall variability.

In addition, it can be seen in Fig. 10 that the profiles B-B' and $\mathrm{C}-\mathrm{C}^{\prime}$ showed greater sensitivity to leakages, mainly due to the geological-geotechnical characteristics and the location of the cuts along the slopes that favoured the decrease in the matrix suction values and therefore induced instability in both profiles. In addition, critical condition, $\mathrm{FS}<1.0$, in profiles $\mathrm{A}-\mathrm{A}^{\prime}$ and $\mathrm{C}-\mathrm{C}^{\prime}$ are verified between days $32 \mathrm{nd}$ and 35 th after the beginning of simulations, in response to the significant rainfall that occurred in this period. However, it is observed that, under the influence of leakage, rainfall history played a role, since the factor of stability is previously before the large rainfall event at the end of the simulation period. This can be seen more clearly in the profile B-B' of Fig. 10: in the dry period between day 15 and day 22 after the beginning of simulation, a quick recovery of the stability of the simulations is verified, which includes the effect of leakage (black curve), which is interrupted with the return of the rainfall.

Finally, in the fourth scenario of Fig. 10 (light-brown line), all the anthropic factors (cut, leakage and housing load) are considered together with the daily rainfall. Most of the time, FS values remained below the threshold of 1.5 in the $\mathrm{A}-\mathrm{A}^{\prime}$ and $\mathrm{B}-\mathrm{B}^{\prime}$ profiles, but only after the day 34 th of the simulation in the case of the profile $\mathrm{C}-\mathrm{C}^{\prime}$. The probability of landslides increased significantly $(\mathrm{FS}<1.0)$ in all profiles from day 32 of the simulation in response to heavy rainfall at the end of the period. In the case of the profile $C-C^{\prime}$ (light-brown line), the inclusion of housing loads appears to provide more stability to the profile, probably related to the fact that the critical failure surface estimated by the numerical model was different from that assumed in scenario 3 (black line).

Based on the assessment of the slope safety factor presented in Fig. 10, it is clear that the probability of landslides associated with the 2000 rainfall on slopes covered with natural vegetation is very low. When considering the influence of rainfall in conjunction with anthropogenic factors, there was a significant decrease in the safety factor in all profiles studied, although the effect varied between slopes depending on the geological-geotechnical profile characteristics, geomorphological conditions, water table position and the anthropic conditions, that is, the positioning of cuts, leakage and housing load along the slope.

In general, slopes became unstable $(\mathrm{FS}<1.0)$ between the 32 nd and 35th days after the beginning of simulations when high daily accumulated values were verified. Since most of the landslide occurred on day 32, it follows that the model successfully predicted the time at which the landslides began. However, it should be noted that previous accumulated rainfall values were crucial to creating favourable conditions for triggering landslides as shown by Fig. 10 after the 30th day from the beginning of the simulation.

Santoro et al. (2010) recommended in situ technical surveys of urban hazardous areas after accumulated $72 \mathrm{~h}$ rainfall equal to 60,80 and $100 \mathrm{~mm}$ (depending on the municipality) in order to identify evidence of the imminence of landslides and to enforce eventual preventive removal of the population. It can be seen in Fig. 10 that the $72 \mathrm{~h}$ of accumulated rainfall was $35 \mathrm{~mm}$ for day 30 after the beginning of simulation, $35 \mathrm{~mm}$ for day 31, $60 \mathrm{~mm}$ for day 32 and $191 \mathrm{~mm}$ for day 33. Thus, critical rainfall thresholds (60-100 mm) were exceeded between the $32 \mathrm{nd}$ and 33 th days for the events recorded in the year 2000.

In this period, the FS in the three analysed profiles presented the lowest values, located exactly between the lowmedium security zone $(1.0<\mathrm{FS}<1.3)$ and the unstable zone $(\mathrm{FS}<1.0)$, which shows that the "anthropic and natural factors integrated analysis method" proposed in this paper successfully predicted the beginning of the landslides. Although the $72 \mathrm{~h}$ rainfall threshold value proposed by Santoro et al. (2010) proved to be valid for the 2000 event, results of the simulation indicated that the rainfall 30 days prior to the landslides was crucial to bringing FS values closer to critical levels, indicating that the critical value presents limitations on slopes that were initially drier.

\section{Conclusions}

The GEO-SLOPE model proved to be an efficient and useful tool with which to predict the landslide in the Campos do Jordão municipality due to the rainfall event of 2000 and allowed to disentangle the effects of cut and fill, construction practices and pipe leakage in three representative slopes of the area. The use of numerical models that perform flow and stability analyses considering the simultaneous influence of natural and anthropic variables were accurate for the prediction of occurrences of landslides on urban slopes.

Regarding the use of critical values of rainfall in early warning systems by CEMADEN and the civil defence for the Campos do Jordão municipality, although adequate for the event of 2000, our study shows that the previous rainfall history, in combination with leakages, played a fundamental role in creating favourable conditions for the occurrence of landslides. This is related to the fact that leakages contribute to keeping the soil profile closer to saturation at the beginning of the period of more intense rainfall, and consequently the developing of positive pore-pressure conditions. In other words, the threshold currently used for issuing early warnings would result in late alarms, at least in heavily disturbed landscapes. 
The results of the stability analyses confirmed the hypothesis that the occurrence of landslides in the study area cannot be attributed solely and exclusively to the rainfall events in the year 2000, despite the significant accumulated values. Therefore, numerical modelling results corroborated the fact that the occurrence of landslides was the combination of natural and anthropic factors, with the decisive influence of the latter, that is, due to the presence of several cuts along the slope combined with construction and leakage. Clearly, human interventions on natural slopes play a fundamental role in triggering landslides in heavily populated steep slopes surrounding urban areas. Since shallow landslides in the study area usually occur in cut-and-fill slopes, the rupture surface size and the amount of material mobilized do not vary significantly among the events. Therefore, the most useful information for an early warning system perspective is to know whether the value of FS is below 1.0, regardless of how far below that threshold the slope safety factor is. Other relevant information is the timing of the landslide events, which is crucial to determining the rainfall thresholds for issuing an early warning. Therefore, information about the rupture surface size, which is essential for assessing potential damages, is beyond the scope of this study.

Considering that the pattern of land use and construction used in the simulations is representative of most neighbourhoods of Brazilian urban areas, the methodology used in this paper needs to be repeated and verified in other areas in order to establish more accurate critical threshold that trigger landslides. Moreover, since the landslide-prone areas of Campos do Jordão municipality are not the most populated of Brazil, for instance, compared to the outskirts of several metropolitan areas, it becomes crucial to verify whether a mosaic of site-specific rainfall thresholds is needed in heavily occupied areas, rather a single regional threshold, as suggested by Segoni et al. (2014). In this context, this study demonstrated that using the slope safety factor is viable for determining a more accurate rainfall threshold that triggers landslides, with direct impacts on the credibility of early warning systems, which relies on minimizing false alarms or premature/late warnings.

Although the results of this study have uncertainties mainly associated with the geotechnical parameters used in the flow analysis and slope stability, it is the first comprehensive analysis of the factors responsible for triggering landslide in Brazil that integrates field evidence, anthropic effects, geotechnical data and numerical simulation. Since simulation results indicated that the slope safety factor FS was sensitive to both geotechnical and anthropic factors, future studies of slope stability probabilistic analysis are needed, which takes into account the wider range of parameters values that occur in the study area.

Finally, considering that this work has demonstrated that the anthropic factors are the main instability factors in urban slopes, it is essential that urban managers and planners promote public policies and enforce laws that restrict the occu- pation of landslide-susceptible areas. Detailed surveys that identify landslide-prone areas are essential, since many urban areas of Brazil lack zoning of hazardous areas, which is essential for implementing regulations. Besides this, educational campaigns regarding the adoption of better construction practices and reduction of piping leakage will be helpful in already consolidated occupied areas.

Data availability. The precipitation data can be accessed through the website: http://www.cemaden.gov.br/mapainterativo/ Geotechnical data and numerical experimental results can be directly requested from the authors.

Competing interests. The authors declare that they have no conflict of interest.

Acknowledgements. Experimental research and field collection were funded by the National Council for Scientific and Technological Development CNPq through the grant 402240/2012-0. We are also grateful to the National Institute of Science and Technology for Climate Change Phase 2 (CNPq grant 465501/2014-1, FAPESP grants 2014/50848-9 and 2015/50122-0, and CAPES grant 16/2014) for covering publication fees.

Edited by: Samuele Segoni

Reviewed by: three anonymous referees

\section{References}

ABNT - Brazilian Association of Technical Standards: Loads for the buildings structures calculation, NBR 6120, Rio de Janeiro, 5 pp., 1980.

ABNT - Brazilian Association of Technical Standards: Determination of the specific mass, NBR-6508, Rio de Janeiro, 8 pp., 1984a.

ABNT - Brazilian Association of Technical Standards: Soil - grain size analysis test, NBR-7181. Rio de Janeiro, 13 pp., 1984b.

ABNT - Brazilian Association of Technical Standards: Soil - determination of the liquid limit, NBR 6459. Rio de Janeiro, 6 pp., $1984 c$.

ABNT - Brazilian Association of Technical Standards: Soil - determination of the plastic limit, NBR 7180. Rio de Janeiro, 3 pp., 1984d.

ABNT - Brazilian Association of Technical Standards: Slopes stability, NBR-11682. Rio de Janeiro, 39 pp., 1991.

ABNT - Brazilian Association of Technical Standards: Rocks and soils - terminology, NBR-6502, Rio de Janeiro, 18 pp., 1995.

Acharya, K. P., Bhandary, N. P., Dahal, R. K., and Yatabe, R.: Seepage and slope stability modelling of rainfall-induced slope failures in topographic hollows, Geomat. Nat. Haz. Risk, 7, 721746, 2016.

Ahrendt, A.: Gravitational mass movements - proposal of a forecast system: application at the urban area of Campos do Jordão City-SP, Brazil. (In Portuguese), Doctoral thesis, School of En- 
gineering of São Carlos, São Paulo University, Brazil, 390 pp., 2005.

Ahrendt, A. and Zuquette, L. V.: Triggering factors of landslides in Campos do Jordão City, Brazil, B. Eng. Geol. Environ., 62, 231-244, 2003.

Almeida, F. F. M.: The system of continental rifts bordering the Santos Basin, Brazil, in: Anais Academia Brasileira de Ciências, Continental Margins Of Atlantic Type, São Paulo, 1975, 48 (Supplement), 15-26, 1976.

Andrade, E.: Risk mapping associated to landslides, flood, erosion and undercutting of riverbank in municipality of Campos do Jordão, São Paulo State, Brazil (in Portuguese), IG-CEDEC Technical Report number 01/2013, 4, 2014.

Baum, R. L., Savage, W. Z., and Godt, J. W.: TRIGRS - a FORTRAN program for transient rainfall infiltration and grid-based regional slope stability analysis, US Geological Survey Open File Report 2002-424, 38 pp., 2002.

Beven, K. J. and Kirkby, M. J.: A physically based variable contributing area model of basin hydrology, Hydrol. Sci. B., 24, 4369, 1979.

Burton, A. and Bathurst, J.: Physically based modelling of shallow landslide sediment yield at a catchment scale, Environ. Geol., 35, 89-99, 1998.

Campbell Scientific: EnviroSCAN ${ }^{\mathrm{TM}}$ soil water content profile probes, Instruction Manual, $48 \mathrm{pp}$., available at: https:// s.campbellsci.com/documents/us/manuals/envirosmart.pdf (last access: 12 July 2017), 2016.

CEDEC - Civil Defense Coordination of the São Paulo State: databases of the summer operation emergency calls from 2000 through 2013 (in Portuguese), São Paulo, 2013.

CEPED - Centro Universitário de Estudos e Pesquisas sobre Desastres. Atlas Brasileiro de Desastres Naturais 1991-2010: volume Brasil, Florianópolis: UFSC, 127 pp., 2012.

Cho, S. E.: Infiltration analysis to evaluate the surficial stability of two-layered slopes considering rainfall characteristics, Eng. Geol., 105, 32-43, 2009.

Coelho Netto, A. L., Avelar, A. S., Vianna, L. G. G., Araújo, I. S., Ferreira, D. L. C., Lima, P. H. M., Silva, A. P. A., and Silva, R. P.: The extreme landslide disaster in Brazil, Landsl. Sci. Pract., 6, 377-384, 2013.

Costa Filho, L. M. and Campos, T. M. P.: Anisotropy of a gneissic residual soil, in: Proceedings of the 9th Pan-American Conference on Soil Mechanics and Foundations Engineering, Vina Del Mar, Chile, 51-61, 1991.

Crosta, G.: Regionalization of rainfall thresholds: an aid to landslide hazard evaluation, Environ. Geol., 35, 131-145, 1998.

D’Orsi, R., D’Ávila, C., Ortigão, J. A. R., Dias, A., Moraes, L., and Santos, M. D.: Rio-Watch: The Rio de Janeiro Landslide Watch System, in: Proceedings of the 2nd Pan-American Symposium on Landslides, Rio de Janeiro, Brazil, 21-30, 1997.

Dietrich, W. E., Asua, R. R., Orr, J. C. B., and Trso, M.: A validation study of the shallow slope stability model, SHALSTAB, in the forest lands of Northern California. Stillwater Ecosystem, Watershed and Riverine Sciences, Berkeley, 59 pp., 1998.

Frattini, P., Crosta, G., and Sosio, R.: Approaches for defining thresholds and return periods for rainfall-triggered shallow landslides, Hydrol. Process., 23, 1444-1460, 2009.
Gasmo, J. M., Rahardjo, H., and Leong, E. C.: Infiltration effects on stability of a residual soil slope, Comp. Geotech., 26, 145-165, 2000.

Geo-Slope: Stability modeling with SLOPE/W: an engineering methodology, User manual, Geo-Slope International, 238 pp., 2012a.

Geo-Slope: Seepage modeling with SEEP/W: an engineering methodology, User manual, Geo-Slope International, 199 pp., 2012b.

GeoStudio: GeoStudio Tutorials includes student edition lessons. Calgary, Alberta, Canadian: Geo-Slope International Ltd., 2012.

Guzzetti, F., Peruccacci, S., Rossi, M., and Stark, C. P.: Rainfall thresholds for the initiation of landslides in central and southern Europe, Meteorol. Atmos. Phys., 98, 239-267, 2007.

Huat, B .B. K., Ali, F. H., and Rajoo, R. S. K.: Stability analysis and stability chart for unsaturated residual soil slope, Am. J. Environ. Sci., 2, 154-160, 2006.

IBGE - Brazilian Institute of Geography and Statistics, social and economic data of the Brazilian citizens (in Portugguese), available at: http://cidades.ibge.gov.br/painel (last access: 23 June 2017), 2016.

Iverson, R. M.: Landslide triggering by rain infiltration, Water Resour. Res., 36, 1897-1910, 2000.

Kim, J., Jeong, S., Park, S., and Sharma, J.: Influence of rainfallinduced wetting on the stability of slopes in weathered soils, Eng. Geol., 75, 251-262, 2004.

Lagomarsino, D., Segoni, S., Fanti, R., and Catani, F.: Updating and tuning a regional-scale landslide early warning system, Landslides, 10, 91-97, https://doi.org/10.1007/s10346-0120376-y, 2013.

Liao, Z., Hong, Y., Wang, J., Fukuoka, H., Sassa, K., Karnawati, D., and Fathani, F.: Prototyping an experimental early warning system for rainfall-induced landslides in Indonesia using satellite remote sensing and geospatial datasets, Landslides, 7, 317-324, https://doi.org/10.1007/s10346-010-0219-7, 2010.

Londe, L. R., Coutinho, M. P., Di Gregório, L. T., Santos, L. B. L., and Soriano, E.: Water related disasters in Brazil: perspectives and recommendations (in Portuguese), Amb. Soc., 17, 133-152, 2014.

Marinho, F. A. M. and Oliveira, O. M.: The filter paper method revisited, Geotech. Test. J., 29, 250-258, 2006.

Modenesi-Gauttieri, M. C. and Hiruma, S. T.: A Expansão Urbana no planalto de Campos do Jordão. Diagnóstico geomorfológico para fins de planejamento. Revista do Instituto Geológico, São Paulo, 25, 1-28, 2004.

Montrasio, L.: Stability analysis of soil slip, in: Proceedings of International Conference BRisk 2000, edited by: Brebbia, C. A., Wit Press, Southampton, 357-366, 2000.

Montrasio, L. and Valentino, R.: A model for triggering mechanisms of shallow landslides, Nat. Hazards Earth Syst. Sci., 8, 1149-1159, https://doi.org/10.5194/nhess-8-1149-2008, 2008.

Montrasio, L., Valentino, R., and Losi, G. L.: Towards a real-time susceptibility assessment of rainfall-induced shallow landslides on a regional scale, Nat. Hazards Earth Syst. Sci., 11, 1927-1947, https://doi.org/10.5194/nhess-11-1927-2011, 2011.

$\mathrm{Ng}, \mathrm{C} . \mathrm{W}$. W. and Shi, Q.: Influence of rainfall intensity and duration on slope stability in unsaturated soils, Q. J. Eng. Geol., 31, 105113, 1998. 
Ogura, AT; Silva, FC; Vieira, AJNL. Zoneamento de risco de escorregamento das encostas ocupadas por vilas operárias como subsídio à elaboração do plano de gerenciamento de áreas de risco da estância climática de Campos do Jordão - SP 2004, in: Simpósio Brasileiro de Desastres Naturais, 1, 2004, Florianópolis, Anais, Florianópolis: GEDN/UFSC, 44-58, (CD-ROM), 2004,

Oh, W. T. and Vanapalli, S. K.: Influence of rain infiltration on the stability of compacted soil slopes, Comp. Geotech., 37, 649-657, 2010.

Pack, R. T., Tarboton, D. G., and Goodwin, C. N.: SINMAP - a stability index approach to terrain stability hazard mapping, User's manual, Terratech Consulting Ltd, Salmon Arm, 1998.

Pack, R. T., Tarboton, D. G., and Goodwin, C. N.: The SINMAP approach to terrain stability mapping, in: Proceedings of the 8th Congress of the International Association of Engineering Geology, Vancouver, Canada, 21-25, 1998.

Rahardjo, H., Ong, T. H., Rezaur, R. B., and Leong, E. C.: Factors controlling instability of homogeneous soil slopes under rainfall, J. Geotech. Geoenviron. Eng., 133, 1532-1543, 2007.

Reis, R. M., Azevedo, R. F., Botelho, B. S., and Vilar, O. M.: Performance of a cubical triaxial apparatus for testing saturated and unsaturated soils, Geotech. Test. J., 34, 1-9, 2011.

Ridente, J. L., Ogura, A. T., Macedo, E. S., Diniz, N. C., Alberto, M. C., and Santos, H. P.: Accidents associated to mass movements that were occurred in municipality of Campos do Jordão, SP, at January 2000: technical actions after the disasters (in Portuguese), IPT publications number 2815, 14 pp., 2002.

Rigon, R., Bertoldi, G., and Over, T. M.: Geotop: a distributed hydrological model with coupled water and energy budgets, J. Hydrometeorol., 7, 371-388, 2006.

Rossi, G., Catani, F., Leoni, L., Segoni, S., and Tofani V.: HIRESSS: a physically based slope stability simulator for HPC applications, Nat. Hazards Earth Syst. Sci., 13, 151-166, https://doi.org/10.5194/nhess-13-151-2013, 2013.

SABESP: Leak tests, http://site.sabesp.com.br/site/interna/Default. aspx?secaoId=244 (last access: 4 April 2016), 2016.
SABESP: Water reduction program not charged, Synthetic report, Sao Paulo: Lyonnaise des Eaux Services Associés - LYSA, 1993.

Santoro, J., Mendes, R. M., Pressinotti, M. M. N., and Manoel, G. R.: Correlation between rainfall and landslides occurred during the operation of the prevention plan of civil defense in State of São Paulo, SP (in Portuguese), in: Proceedings of the 7th Brazilian Symposium on Geotechnical and Geoenvironmental Cartography, Maringá, Paraná, 1-15, 2010.

Segoni, S., Rosi, A., Rossi, G., Catani, F., and Casagli, N.: Analysing the relationship between rainfalls and landslides to define a mosaic of triggering thresholds for regional-scale warning systems, Nat. Hazards Earth Syst. Sci., 14, 2637-2648, https://doi.org/10.5194/nhess-14-2637-2014, 2014.

Tatizana, C., Ogura, A. T., Cerri, L. E. S., and Rocha, M. C. M.: Numerical modeling of the analysis of correlation between rainfall and landslides applied to the slopes of the Serra do Mar in municipality of Cubatão (in Portuguese), in: Proceedings of the 2nd Brazilian Congress of Engineering Geology, 237-248, 1987.

Terlien, M. T.: The determination of statistical and deterministic hydrological landslide triggering thresholds, Environ. Geol., 35, 124-130, 1998.

Thiebes, B., Bell, R., Glade, T., Jäger, S., Mayer, J., Anderson, M., and Holcombe L.: Integration of a limit-equilibrium model into a landslide early warning system, Landslides, 11, 859-875, https://doi.org/10.1007/s10346-013-0416-2, 2014.

Tofani, V., Dapporto, S., Vannocci, P., and Casagli, N.: Infiltration, seepage and slope instability mechanisms during the 20-21 November 2000 rainstorm in Tuscany, central Italy, Nat. Hazards Earth Syst. Sci., 6, 1025-1033, https://doi.org/10.5194/nhess-61025-2006, 2006.

Van Asch, T. W. J., Buma, J., and Van Beek, L. P. H.: A view on some hydrological triggering systems in landslides, Geomorphology, 30, 25-32, 1999.

Van Genuchten, M. T.: A closed-form equation for predicting the hydraulic conductivity of unsaturated soils, J. Soil Sci. Soc. Am., 44, 892-898, 1980. 